\title{
A 30 kg Capacity High Precision Load Cell Mass Comparator
}

\author{
Randall M. Schoonover* \\ National Bureau of Standards, Washington, DC 20234
}

April 15, 1981

\begin{abstract}
Described here are simple means to fabricate a $30 \mathrm{~kg}$ mass comparator based on an ordinary direct reading load cell. The mass comparator performs with a precision of $1 \mathrm{ppm}$.
\end{abstract}

Key Words: Constant loading; high precision; load cell; mass comparator; substitution weighing; weighing.

\section{Introduction}

A paper $[1]^{1}$ describing a high precision load cell mass comparator was published in 1979. The principle of that device was the maintenance of a spring force on the active load cell element nearly equal to the gravitational forces of the weights being compared, even during the period when weights were exchanged. Doing so caused an ordinary load cell which had a precision of $l$ part in 10,000 as a direct reading instrument to perform with a precision of a few parts per million (ppm) as a mass comparator. This work was with loads of $225 \mathrm{~kg}$, and it was speculated that scaling the method to $30 \mathrm{~kg}$ would be quite useful in small-mass metrology. Personal communication with several members of the measurement community, however, revealed their unanimous opinion that such scaling would result in serious loss of precision.

The work reported here results from the successful fabrication of a $30 \mathrm{~kg}$ mass comparator based on the above principle that has a precision of about $1 \mathrm{ppm}$.

\section{The Instrument}

The comparator differs significantly in design from the 225 $\mathrm{kg}$ version in several ways. The instrument is self-supporting and is provided with a built-in weight exchanger as shown in figure 1 . This feature not only loads the cell without shock, but also aligns the weight in the center of the weighing pan. The cell itself is supported by four parallel springs in tension rather than a single spring in compression as before. Finally, the flexure universals above and below the cell are replaced with gimbaled joints fabricated from ball bearing assemblies. The load cell incorporates a solid state bridge and has a capacity of $45 \mathrm{~kg}(100 \mathrm{lb}$.). A schematic view of the load cell and spring assembly is shown in figure 2.

* Cenler for Absolute Physical Quantities, National Measurement Laboratory.

1 Figures in baackets indicate literature references at the end of this paper.

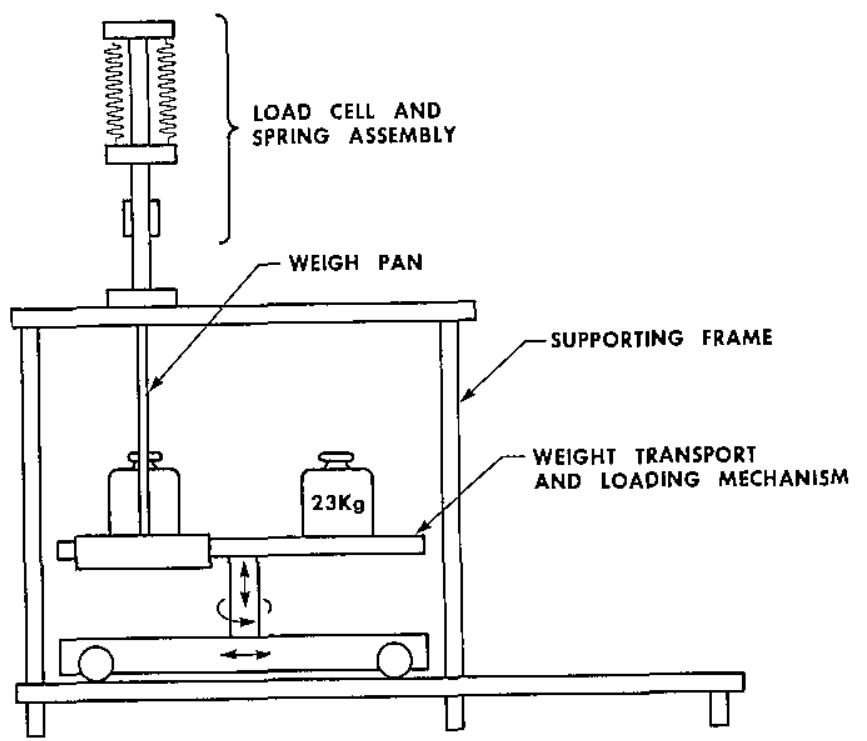

FIGURE 1. Cross-sectional view showing the essential components of the constant loading mechanism.

It is noteworthy to report one major operational change in the use of the comparator. Unlike the previous instrument the springs are used to support the load cell during the weighing mode, whereas before a mechanical shunt intervened and supported the cell. This method of supporting the cell appears to improve the isolation from ambient vibration as has been observed independently by others [2]. In addition nearly 100 percent of the load is maintained on the cell at all times.

\section{Test Results}

The test weighings were made in the usual manner, that is, six double substitutions between two $23 \mathrm{~kg}$ weights (50 lb.) comprised one test. The data was reduced and the standand deviation was calculated in the usual way. 


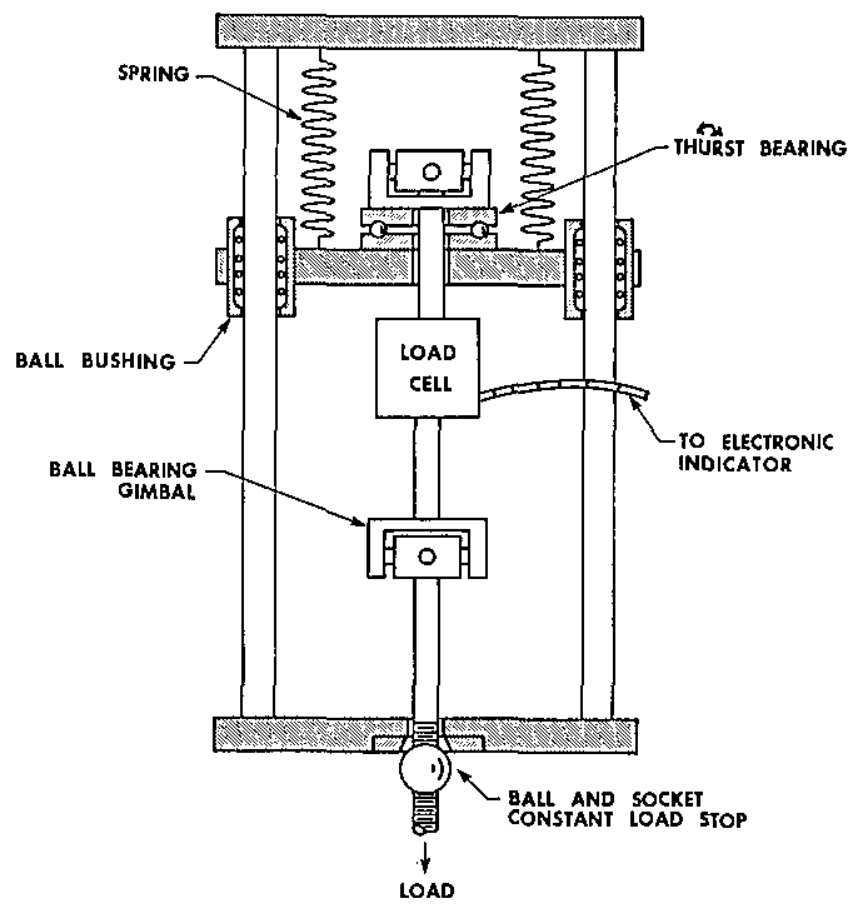

FGURE 2. A schematic view of the complete weighing system.

Three different electronic load cell voltage measuring instruments were used in collecting the data and the pooled standard deviation, $S D_{p}$, for each group of three tests is given in the following table.

\begin{tabular}{ccc}
\hline $\begin{array}{c}\text { Current Bridge Used } \\
\text { in Ref. 1 }\end{array}$ & DJ101 [3] & $\begin{array}{c}\text { Cutkosky \& Davis [4] } \\
\text { Bridge }\end{array}$ \\
\hline$S D_{\rho} 58 \mathrm{mg}$ & $24 \mathrm{mg}$ & $30 \mathrm{mg}$ \\
\hline
\end{tabular}

The Cutkosky and Davis circuit was especially adapted for this application. That data was supplied by R. S. Davis (personal communication).
During the above testing the mass comparator was uncased and exposed to the detrimental effects, if any, of air circulation in the laboratory.

\section{Discussion}

A standard deviation of $24 \mathrm{mg}$ for a $30 \mathrm{~kg}$ comparator is about $l \mathrm{ppm}$ of the applied load. A review of commercial mechanical instruments of this capacity that contain knife edges or flexure bearings indicate that the units from a given manufacturer have a standard deviation, when used as a mass comparator, which varies between 1 and $20 \mathrm{mg}$. It appears to the author, that if more effort is given to the load cell and associated electronic indicator design and careful attention is paid to ambient vibration isolation, this device would outperform the conventional mass comparator and operate with a precision a few parts in $10^{7}$ or better. This instrument would be more rugged, would reduce the measurement time, provide much more on-scale range, and, because of its mechanical simplicity be of substantially lower cost.

The author wishes to thank Albert Tholen of the National Bureau of Standards Office of Weights and Measures for financial support for this work.

\section{References}

[1] Schoonover, Randall M. A high precision load cell mass comparator. J. Res. Nat. Bur. Stand. (U.S.). 84(5): 347-351; 1979 September-October.

[2] Page, Dennis. White Sands Missile Range, personal communication.

[3] The DJ10l is a commercial device manufactured by DJ Instruments, Inc., and was on loan for this test from NBS Division 737. Certain trade names and company products are identified in order to adequately specify the experimental procedure. In no case does such identification imply recommendation or endorsement by the National Bureau of Standards nor does it imply that the products are necessarily the best available for the purpose.

[4] Cutkosky, R.D.; Davis, R.S. A simple control circuit for temperature regulation and other bridge applications. Accepted for publication in Rev. Sci. Instr. 